\title{
Rancang Bangun Sistem Telekomunikasi Konvergen Berbasis Voice over Internet Protocol Menggunakan Virtualbox
}

\author{
Yudha Aditya $^{1)}$, Adian Fatchur Rochim ${ }^{2)}$, Eko Didik Widianto ${ }^{2)}$ \\ Program Studi Sistem Komputer, Fakultas Teknik, Universitas Diponegoro \\ Jl. H. Prof. Sudarto, S.H. Tembalang, Semarang, Indonesia \\ E-mail: yudha.adityaa@yahoo.com
}

\begin{abstract}
Abstrak- Perkembangan teknologi yang sangat pesat, membuat teknologi telekomunikasi semakin berkembang. Voice over Internet Protocol (VoIP), Public Switched Telephone Network (PSTN), Global System for Mobiles (GSM) dan internet adalah teknologi terkini dalam memenuhi kebutuhan seseorang dalam berkomunikasi. Di sebagian besar implementasinya, penyedia layanan PSTN dan GSM memberikan sebuah tarif dalam setiap panggilan yang terjadi. Perancangan dan pembangunan sistem ini bertujuan untuk menciptakan sebuah sistem telekomunikasi berbasis VoIP, yang dapat menghubungkan jaringan lokal, GSM dan internet secara terpusat, demi memenuhi kebutuhan komunikasi seseorang dengan mobilitas tinggi disertai fleksibilitas pengaturan alur panggilan, untuk menghemat anggaran penggunaan layanan telekomunikasi.
\end{abstract}

Metodologi penelitian tugas akhir ini dibagi menjadi 4 tahapan. Tahapan tersebut diantaranya adalah definisi sistem, spesifikasi kebutuhan, konfigurasi sistem dan pengujian sistem. Definisi sistem dibuat dengan mendefinisikan gambaran dan cara kerja sistem secara umum. Spesifikasi kebutuhan dibuat dengan menyesuaikan kebutuhan perangkat keras dan perangkat lunak yang dibutuhkan oleh sistem. Konfigurasi dilakukan untuk mengimplementasikan pengaturan mengenai dialplan, Interactive Voice Response (IVR) dan kotak suara. Pengujian sistem adalah tahap untuk memeriksa keseluruhan fungsi pada sistem.

Sistem ini diuji dengan melakukan panggilan dari setiap klien. Hasil dari pengujian menunjukkan bahwa sistem mampu memenuhi kebutuhan komunikasi seseorang dengan mobilitas tinggi. Fleksibilitas pengaturan panggilan membuat sistem dapat berkomunikasi dengan jaringan GSM dan VoIP Rakyat serta dapat menghemat tarif penggunaan layanan telekomunikasi. Sistem juga dapat mencatat aktivitas panggilan dengan memanfaatkan fitur Call Detail Record (CDR).

Penelitian ini dapat dijadikan sebagai alternatif bagi perkantoran maupun instansi, untuk menggunakan layanan telekomunikasi secara terpusat, agar penghematan anggaran dalam penggunaan telekomunikasi menjadi lebih efisien.

Kata Kunci: Telekomunikasi, VoIP, GSM, IP PBX, Asterisk, Dialplan.

\section{PENDAHULUAN}

$\mathrm{K}$ omunikasi suara seperti telepon seluler melalui jaringan GSM, dapat dilakukan melalui suatu jaringan komputer tanpa dibatasi oleh jarak tempuh. Voice Over Internet Protocol (VoIP) merupakan sebuah teknologi inovasi yang menjadikan jaringan internet ataupun jaringan lokal komputer, sebagai media transmisi paket data suara agar pengguna dapat berkomunikasi satu sama lain. Terdapat penelitian terdahulu yang menyatakan bahwa jaringan VoIP dapat terhubung dengan jaringan GSM. ${ }^{[1]}$ Implementasi VoIP pada jaringan komputer dapat digunakan untuk membantu kebutuhan komunikasi pengguna bermobilitas tinggi yang terhubung dengan jaringan lokal.

Berdasarkan latar belakang masalah tersebut, dapat dibuat suatu perumusan masalah, yaitu Bagaimana mengimplementasikan sistem Voice over Internet Protocol guna memenuhi kebutuhan komunikasi seseorang dengan mobilitas tinggi secara konvergen untuk menghemat anggaran penggunaan layanan telekomunikasi.

Tugas akhir ini bertujuan untuk menghasilkan sistem telekomunikasi yang terpusat pada sistem VoIP guna memenuhi kebutuhan berkomunikasi dengan mobilitas yang tinggi dengan fleksibilitas dalam pengaturan alur panggilan guna menghemat anggaran penggunaan layanan telekomunikasi.

Terdapat pembahasan masalah yang memiliki batasan pada penelitian ini, diantaranya adalah: sistem berupa implementasi sistem telekomunikasi VoIP yang dapat membuat serta menerima panggilan dari jaringan GSM dan jaringan VoIP Rakyat. Kemudian, sistem dijalankan pada server menggunakan aplikasi mesin virtual yaitu Oracle VM Virtual Box 4.3.8 yang berfungsi sebagai server dengan sistem operasi Ubuntu Server 12.04.5 LTS dan menggunakan aplikasi Asterisk 11.13.0 sebagai IP PBX. Sistem ini hanya dapat melayani panggilan suara, dengan menggunakan codec a-law dan $u$-law.

Pengguna dapat terhubung dengan sistem menggunakan softphone X-Lite 4.7.1 yang terpasang pada komputer dengan sistem operasi Windows 7 Ultimate 64-bit dan softphone Join 2.2.1 yang terpasang pada perangkat bergerak. Sistem tidak melayani panggilan koferensi dan dalam penelitian ini, penulis tidak membahas performansi dan masalah keamanan informasi.

\section{LANDASAN TEORI}

\section{A. Voice over Internet Protocol (VoIP)}

Voice over Internet Protocol didefiniskan sebagai salah satu bentuk layanan multimedia dan multimedia real-time di dalam jaringan komputer berupa komunikasi suara memanfaatkan saluran komunikasi telepon berbasiskan alamat jaringan $(\text { Alamat IP })^{[2]}$. Dalam definisi sederhana, Voice Over Internet

1) Mahasiswa Program Studi Sistem Komputer Fakultas Teknik Universitas Diponegoro

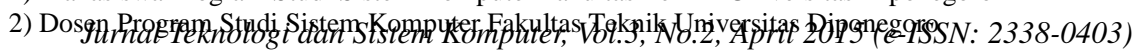

JTsiskom - 282 
Protocol adalah jaringan telepon yang berkomunikasi melalui protokol TCP/IP pada jaringan internet atau intranet ${ }^{[3]}$. Cara kerja VoIP secara umum ditunjukkan oleh Gambar 1.

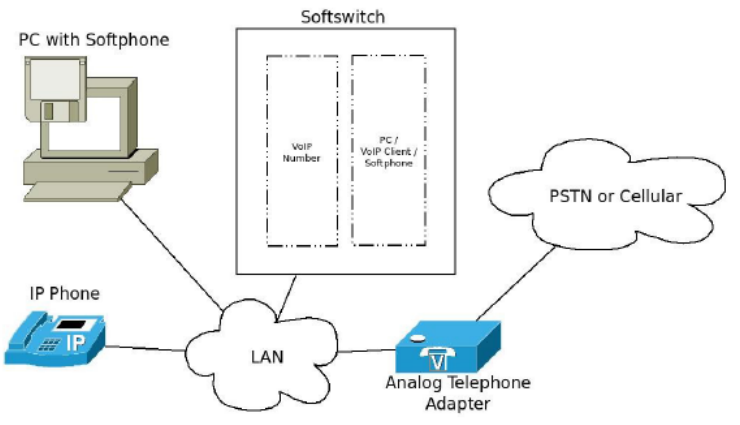

Gambar 1 Bagan kerja VoIP secara umum ${ }^{[3]}$

\section{B. Session Inititiation Protocol (SIP)}

Session Initiation Protocol adalah sebuah kontrol protokol pada layer aplikasi yang dapat membangun, memodifikasi dan mengakhiri sesi multimedia atau panggilan. SIP merupakan salah satu protokol utama yang digunakan untuk mengimplementasikan teknologi $\mathrm{VoIP}^{[4]}$. Contoh pembentukan sesi SIP ditunjukkan oleh Gambar 2.

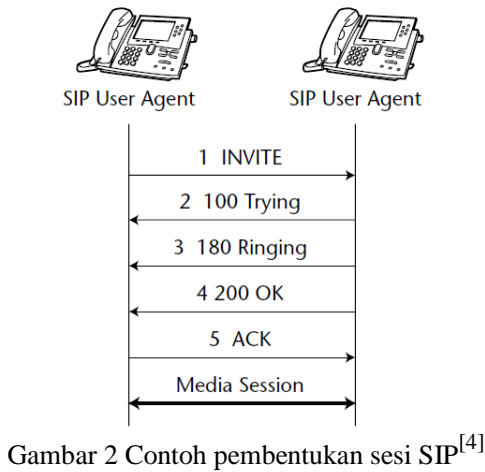

- Protokol pendukung SIP

SIP menggunakan protokol User Datagram Protocol (UDP) dan Transmission Control Protocol (TCP) sebagai protokol transport. Protokol yang mendukung SIP antara lain:

1) Real-Time Transport Protocol (RTP)

Protokol RTP menyediakan transfer media pada jaringan paket secara real-time. Protokol RTP menggunakan protokol UDP dan header RTP mengandung informasi kode bit yang spesifik pada tiap paket.

2) Real-Time Transport Control Protocol (RTCP)

Protokol RTCP merupakan protokol yang mengendalikan transfer media. Protokol ini bekerja sama dengan protokol RTP dalam proses transfer media yang terjadi ${ }^{[5]}$.

\section{Global System for Mobiles (GSM)}

Global System for Mobiles merupakan sebuah standar untuk komunikasi perangkat bergerak yang menggunakan teknologi digital pada frekuensi $900 \mathrm{MHz}$. GSM menggunakan Time Division Multiple Access (TDMA) untuk mengkonversi suara dan mengakses informasi ke dalam data digital ${ }^{[6]}$.

TDMA adalah sebuah teknologi digital yang memungkinkan beberapa pengguna menggunakan saluran suara yang sama dimana setiap percakapan ditransmisikan secara bergantian dalam segmen yang singkat ${ }^{[7]}$.

\section{Private Branch Exchange (PBX)}

Private Branch Exchange didefiniskan sebagai sebuah perangkat yang menangani hampir semua fitur dan fungsi dari pusat perkantoran atau switch telepon, Velepon, internal terhubung dengan PBX dan kemudian PBX menghubungkannya dengan jaringan penyedia layanan telepon. PBX dapat menyediakan segala jenis layanan yang terdapat pada telepon, termasuk Voice Over Internet Protocol ${ }^{[3]}$.

\section{E. Coding-Decoding (Codec)}

Coding dan decoding merupakan sebuah proses konversi suara ke dalam paket data yang dikirimkan ke dalam jaringan. Ketika paket tersebut telah sampai tujuan, paket perlu dikonversi kembali ke dalam suara agar dapat didengar oleh seseorang ${ }^{[8]}$.

\section{F. Dual-Tone Multi-Frequency (DTMF)}

Dual-Tone Multi-Frequency adalah persinyalan yang dihasilkan oleh satu set telepon atau dapat juga dihasilkan oleh PBX. Digit DTMF dapat digunakan oleh entitas seperti gateway atau aplikasi server dalam jaringan protokol internet, switch telepon dan Interactive Voice Response (IVR) dalam sirkuit jaringan switched.Interactive Voice Response (IVR) ${ }^{[9]}$.

\section{G. Interactive Voice Response (IVR)}

Interactive Voice Response adalah sebuah mesin yang menerima sinyal DTMF atau perintah suara dan mengeksekusi beberapa logika guna berinteraksi dengan pengguna menggunakan petunjuk rekaman atau suara sintetis ${ }^{[10]}$. Interactive Voice Response yang dikenal dengan singkatan IVR merupakan sebuah teknologi untuk mengatur respon otomatis kapanpun ketika sebuah panggilan masuk ${ }^{[11]}$.

\section{H. Dialplan}

Dialplan merupakan sebuah skema rencana penomoran yang digunakan dalam telekomunikasi untuk mengalokasikan susunan nomor telepon pada sebuah negara, negara bagian, perkantoran dan jaringan perangkat bergerak. Skema ini mendefinisikan alur yang diatur untuk setiap nomor yang terdaftar pada perangkat.

Dalam merancang sebuah dialplan, terdapat empat buah atribut yang harus dipertimbangkan agar dapat mempermudah proses implementasi. Diantaranya adalah:

- Memiliki dampak yang minim pada sistem yang telah tertanam

- Memiliki dampak yang minim pada setiap pengguna yang menggunakan sistem

- Konfigurasi yang dapat diterjemahkan atau dipahami dengan mudah

- Mengantisipasi pertumbuhan pada sistem ${ }^{[12]}$.

\section{Asterisk}

Asterisk didefinisikan sebagai sebuah platform konvergensi telepon open-source yang dirancang untuk dijalankan pada Linux. Astersik mengkombinasikan lebih dari 100 tahun pengetahuan tentang telepon ke dalam sebuah rangkaian aplikasi telekomunikasi terintegrasi yang padat dan kokoh ${ }^{[13]}$.

Asterisk bertindak sebagai PBX, menyediakan seluruh fitur panggilan konvensional pada stasiun antarmuka dengan cara vitual. ${ }^{[14]}$

\section{J. Mesin Virtual}

Mesin virtual adalah sebuah implementasi perangkat lunak pada mesin komputer yang dapat menjalankan program yang sama seperti layaknya sebuah komputer aslinya. Mesin virtual (virtual machine) mirip dengan pendekatan terlapis dengan sedikit tambahan berupa antarmuka yang 
menghubungkan hardware dengan kernel untuk tiap-tiap $\operatorname{proses}^{[15]}$.

\section{III.PERANCANGAN DAN IMPLEMENTASI SISTEM}

Perancangan sistem ini menjelaskan tentang kebutuhan sistem dan metode yang digunakan untuk merancang arsitektur sistem, topologi jaringan dan perangkat lunak. Metode yang digunakan dalam perancangan tugas akhir ini terdiri atas 2 tahapan, yaitu: definisi sistem dan spesifikasi kebutuhan. Implementasi dilakukan dengan konfigurasi pada sistem, mengikuti rancangan yang sudah dirancang pada tahap sebelum implementasi.

\section{A. Definisi Sistem}

Definisi sistem akan menjabarkan deskripsi umum sistem, arsitektur sistem, topologi jaringan dan cara kerja sistem yang akan digunakan untuk menentukan spesifikasi kebutuhan sistem pada tahap selanjutnya.

\section{1) Deskripsi Umum Sistem}

Dalam tugas akhir ini, teknologi VoIP dikembangkan agar jaringan lokal VoIP dapat berkomunikasi dengan jaringan GSM dan jaringan VoIP lain yaitu VoIP Rakyat melalui jaringan internet agar terbentuk sebuah sistem telekomunikasi secara terpusat/konvergen guna mencapai tujuan dari penelitian. Sistem telekomunikasi konvergen berbasis VoIP adalah pokok bahasan pada penelitian tugas akhir ini.

Sistem ini menggunakan metode virtualisasi, yaitu pembuatan suatu bentuk perangkat virtual dengan sesuatu yang bersifat fisik. Perangkat tersebut berupa server, berfungsi sebagai IP PBX yang terhubung dengan perangkat lainnya seperti GSM gateway, router, telepon seluler dan perangkat bergerak. Sistem bersifat purwarupa sehingga memungkinkan masih adanya kesalahan dan kekurangan pada sistem.

\section{2) Arsitektur Sistem}

Dibutuhkan sebuah server yang berfungsi sebagai PBX agar alur panggilan masuk dan keluar dapat diatur sesuai dengan kebutuhan sistem. PBX yang digunakan dalam sistem ini adalah IP PBX.

Sistem terpusat pada satu titik dimana server IP PBX berfungsi sebagai titik poros yang menyimpan data klien dan mengatur segala aktifitas panggilan pada sistem. Arsitektur sistem telekomunikasi konvergen berbasis VoIP ditunjukkan oleh Gambar 3.

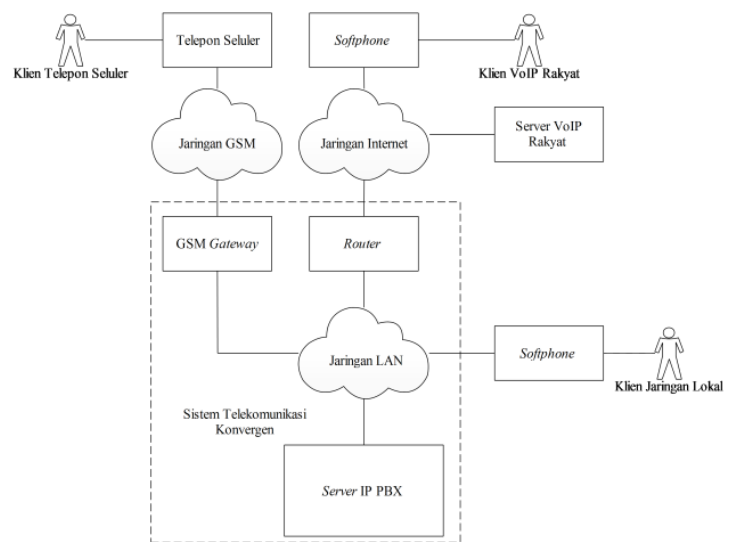

Gambar 3 Arsitektur sistem telekomunikasi konvergen berbasis VoIP

Klien pada tugas akhir ini terdaftar sebagai klien SIP yang menggunakan protokol persinyalan SIP dan komunikasi data ditransmisikan melalui protokol jaringan TCP/IP.

Server virtual dengan sistem operasi Ubuntu Server 12.04.5 LTS terpasang pada sebuah laptop dengan sistem operasi
Windows 7 Ultimate menggunakan aplikasi Oracle VM VirtualBox 4.3.8. Server menggunakan aplikasi Asterisk agar server dapat berfungsi sebagai IP PBX. Gambar 4 menunjukkan arsitektur server IP PBX virtual yang dibangun pada sebuah komputer.

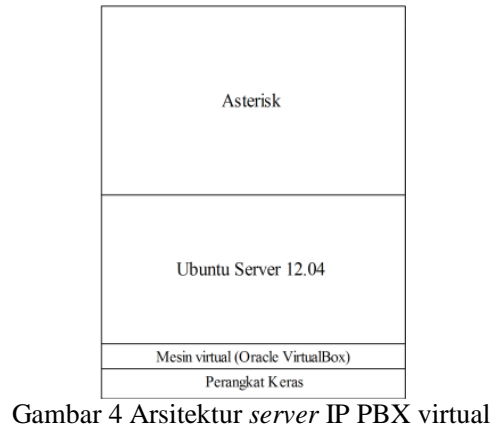

\section{3) Topologi Jaringan}

Sistem ini memiliki rancangan topologi jaringan agar setiap perangkat yang digunakan dapat saling berkomunikasi. Topologi jaringan merupakan hal yang menjelaskan hubungan geometris antara unsur-unsur dasar penyusun jaringan, yaitu node, link, dan station. Topologi jaringan pada sistem ini dirancang dan disusun sesuai kebutuhan sistem dengan perangkat-perangkat yang dibutuhkan oleh sistem. Berikut merupakan penjelasan tentang topologi jaringan dari sistem telekomunikasi konvergen berbasis VoIP:

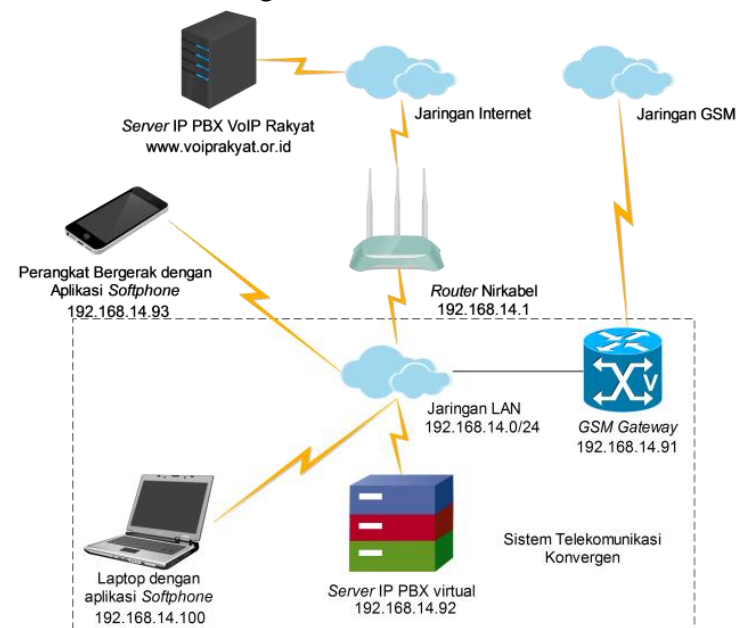

Gambar 5 Topologi jaringan pada sistem telekomunikasi konvergen berbasis VoIP

Gambar 5 menjelaskan tentang topologi jaringan pada sistem telekomunikasi konvergen berbasis VoIP. Pada gambar tersebut, terdapat beberapa perangkat telekomunikasi yang terhubung dengan server virtual melalui router dan GSM gateway.

IP PBX dalam sistem ini berfungsi sebagai perangkat yang mengatur alur komunikasi telepon dan transimisi data berbasis teknologi protokol internet serta mengendalikan ekstensi telepon. Terdapat teknologi IVR dan layanan kotak suara pada IP PBX agar klien dapat memilih tujuan ekstensi telepon dan meninggalkan pesan.

GSM gateway dalam sistem ini berfungsi sebagai media komunikasi dan transmisi data antara jaringan sistem VoIP dengan jaringan GSM sehingga pengguna telepon seluler dan pengguna pada sistem VoIP dapat saling berkomunikasi. Perangkat ini telah terisisip kartu SIM agar perangkat dapat terhubung dengan jaringan GSM.

Jaringan internet digunakan untuk mengakses server VoIP Rakyat agar klien dari jaringan VoIP Rakyat dapat menerima panggilan dari klien lokal sistem VoIP.

4) Cara Kerja Sistem

ISSN: 2338-0403) 
Sistem ini akan bekerja ketika sistem telah memiliki 4 buah klien yang terdaftar pada IP PBX. Klien tersebut diantaranya adalah: klien Join, klien VoIP, klien GSM dan klien VoIP Rakyat. Setiap klien diharapkan bisa saling berkomunikasi agar tercipta sebuah sistem telekomunikasi konvergen berbasis VoIP. Penjelasan mengenai penggunaan nomor ekstensi klien dan tujuannya dijelaskan pada Tabel 1 .

TABEL 1

PENGGUNAAN NOMOR EKSTENSI

\begin{tabular}{|c|c|c|c|}
\hline No. & Nomor Ekstensi & Nama Klien & Keterangan \\
\hline 1. & 2001 & Join & $\begin{array}{l}\text { Digunakan oleh } \\
\text { Softphone Join }\end{array}$ \\
\hline 2. & 2002 & X-lite & $\begin{array}{l}\text { Digunakan oleh } \\
\text { Softphone X- } \\
\text { Lite }\end{array}$ \\
\hline 3. & 2004 & GSM & \multirow{2}{*}{$\begin{array}{l}\text { Digunakan oleh } \\
\text { GSM gateway }\end{array}$} \\
\hline 4. & 082137508567 & Telkomsel & \\
\hline 5. & 146409 & VoIP Rakyat & $\begin{array}{l}\text { Digunakan oleh } \\
\text { Akun VoIP } \\
\text { Rakyat }\end{array}$ \\
\hline
\end{tabular}

\section{- Cara Kerja Panggilan Keluar}

Softphone yang sudah terhubung dengan jaringan lokal sistem telekomunikasi berbasis VoIP dapat melakukan panggilan keluar sesuai dengan alur panggilan yang diatur pada IP PBX. Panggilan tersebut akan diarahkan sesuai dengan nomor yang terdapat pada ekstensi tujuan, cara kerja panggilan keluar ini akan dijelaskan oleh diagram alir yang ditunjukkan pada Gambar 6.

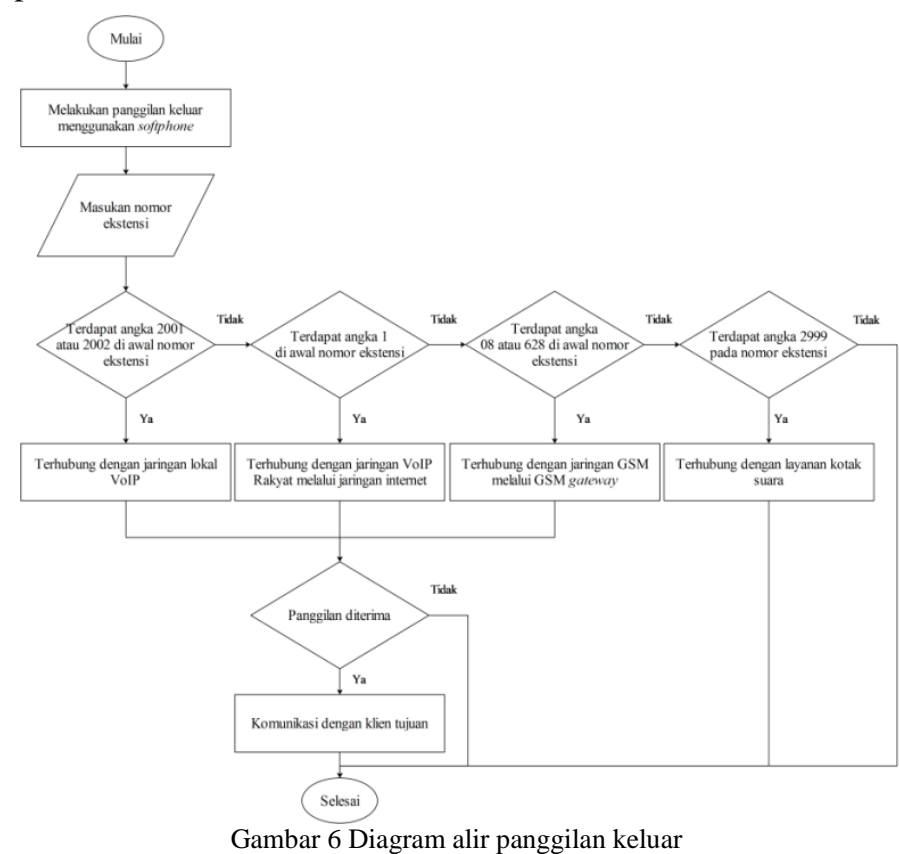

Gambar 6 menjelaskan bahwa klien melakukan panggilan menggunakan softphone dengan nomor ekstensi yang terdaftar dan sudah terhubung dengan jaringan lokal. Disaat nomor ekstensi dimasukkan, IP PBX akan mengecek terlebih dahulu masukan tersebut sebelum mengizinkan panggilan keluar, berikut adalah penjelasan tentang kondisi mengenai cara kerja panggilan keluar:

1. Jika panggilan yang dituju adalah klien pada jaringan lokal VoIP, maka panggilan akan diteruskan dan diarahkan melalui jaringan lokal kemudian klien akan langsung terhubung dengan klien tujuan.
2. Jika panggilan yang dituju adalah klien pada jaringan VoIP Rakyat, maka panggilan akan diteruskan dan diarahkan melalui jaringan internet kemudian klien terhubung dengan jaringan VoIP Rakyat.

3. Jika panggilan yang dituju adalah klien pada jaringan GSM, maka panggilan akan diteruskan dan diarahkan melalui GSM gateway kemudian klien terhubung dengan jaringan GSM.

4. Jika panggilan yang dituju adalah layanan kotak suara, maka panggilan akan diteruskan dan diarahkan ke layanan kotak suara pada IP PBX melalui jaringan lokal.

5. Jika nomor ekstensi tidak dikenali oleh IP PBX atau panggilan tidak diterima oleh klien tujuan maka proses panggilan akan diakhiri.

\section{- Cara Kerja Panggilan Masuk}

Panggilan yang masuk melalui sistem ini akan diproses oleh IP PBX agar sistem dapat mengidentifikasi klien serta mengatur alur panggilan masuk sehingga pengguna dari luar sistem yang melakukan panggilan dapat berkomunikasi dengan klien yang terdaftar pada sistem ini. Cara kerja panggilan masuk akan dijelaskan oleh diagram alir yang ditunjukkan pada Gambar 7.

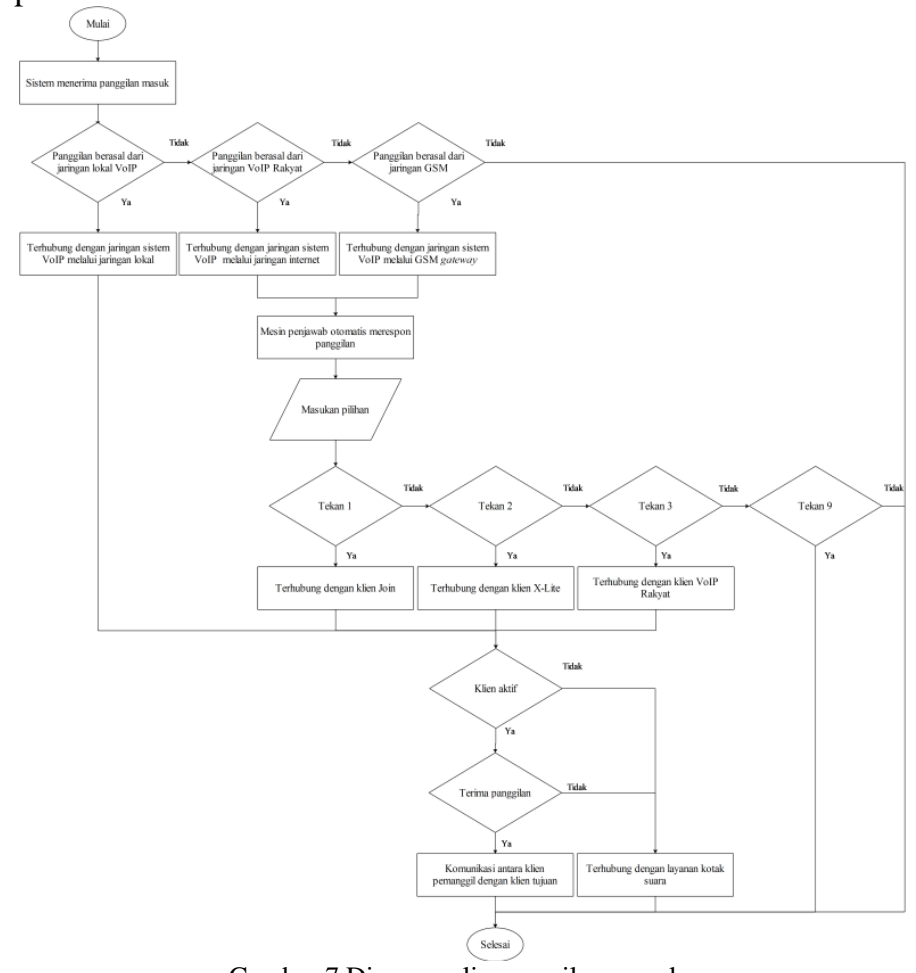

Gambar 7 Diagram alir panggilan masuk

Gambar 7 menjelaskan bahwa terdapat teknologi IVR atau mesin penjawab otomatis pada sistem ini agar klien dari luar sistem dapat memilih klien yang akan dituju. Berikut merupakan alur panggilan masuk yang dirancang agar klien dari luar sistem dapat berkomunikasi dengan klien di dalam sistem:

1. Jika panggilan masuk berasal dari jaringan GSM maka panggilan akan masuk melalui GSM gateway. Kemudian perangkat tersebut meneruskan panggilan kepada IP PBX dan akan diterima oleh teknologi IVR.

2. Jika panggilan berasal dari jaringan VoIP Rakyat maka panggilan akan masuk melalui jaringan internet. Kemudian IP PBX akan menerima panggilan tersebut melalui klien VoIP rakyat dan akan diterima oleh teknologi IVR.

3. Jika panggilan berasal dari jaringan lokal VoIP maka IP PBX akan mengarahkan panggilan langsung kepada klien yang dituju tanpa melalui teknologi IVR. 
4. Apabila klien dalam sistem tidak aktif atau menolak panggilan yang masuk, maka IP PBX akan meneruskan panggilan kepada layanan kotak suara.

Teknologi IVR merespon panggilan masuk dengan data rekaman yang terdapat pada IP PBX lalu menginformasikan tentang angka yang harus ditekan jika ingin terhubung dengan sistem. Masukan angka tersebut dibaca oleh IP PBX sebagai sinyal masukan DTMF dan kemudian akan diteruskan kepada klien di dalam sistem sesuai dengan alur panggilan yang diatur dalam dialplan.

B. Spesifikasi Kebutuhan

1) Spesifikasi Perangkat Keras

TABEL 2

SPESIFIKASI PERANGKAT KERAS

\begin{tabular}{|c|c|c|}
\hline No. & Perangkat Keras & Spesifikasi \\
\hline 1. & Laptop & $\begin{array}{l}\text { Processor: } \\
\text { Intel(R) Core(TM) i5 } \\
\text { Processor 430M } \\
\text { (4CPUs), 2.3GHz } \\
\text { RAM: } \\
\text { 4096MB RAM } \\
\text { VGA: } \\
\text { ATI Mobility Radeon HD } \\
5470 \text { (512MB) } \\
\text { System Manufacture: } \\
\text { Acer } \\
\text { System Model: Aspire } \\
\text { 4745G }\end{array}$ \\
\hline 2. & Router Nirkabel & $\begin{array}{l}\text { Brand: } \\
\text { TP-LINK } \\
\text { Model: } \\
\text { Portable 3G/4G Wireless } \\
\text { N Router } \\
\text { Tipe: } \\
\text { 3G Router } \\
\text { Part Number: } \\
\text { TL-MR3220 }\end{array}$ \\
\hline 3. & GSM Gateway & $\begin{array}{l}\text { Brand: } \\
\text { GoIP } \\
\text { Processor: } \\
\text { ARM9E } \\
\text { Channels: } \\
1 \text { Channel } \\
\text { Interfaces: } \\
2 \text { 10/100 BaseT Ethernet } \\
\text { ports full compliant with } \\
\text { IEEE. } 802.3\end{array}$ \\
\hline 4. & Perangkat Bergerak & $\begin{array}{l}\text { Apple iPhone 4s, Nokia } \\
110\end{array}$ \\
\hline
\end{tabular}

2) Spesifikasi Perangkat Lunak

TABEL 3

SPESIFIKASI PERANGKAT LUNAK

\begin{tabular}{|c|c|c|}
\hline & \multirow{2}{*}{$\begin{array}{l}\text { melalui termin } \\
\text { ubuntu*CLI> }\end{array}$} \\
\hline No. & Perangkat Lunak & \\
\hline 1. & Sistem Operasi Windows 7 Ultimate 64-bit & Konfigura \\
\hline 2. & Oracle VM VirtualBox 4.3 .8 & dikenali oleh \\
\hline 3. & Ubuntu Server 12.04.5 LTS & menunjukka \\
\hline 4. & Asterisk 11.13 .0 & \\
\hline 5. & $\begin{array}{lllll}\text { Digium } & \text { Asterisk } & \text { Hardware } & \text { Device } & \text { Interface } \\
\text { (DAHDI) } 2.10 .0 .1 & & & \end{array}$ & \\
\hline 6. & LibPRI 1.4 .15 & \\
\hline 7. & X-Lite 4.7.1 & \\
\hline 8. & WinSCP & \\
\hline 9. & Join $2.2,1$ & \\
\hline
\end{tabular}

Gambar 10 Tampilan terminal Asterisk
Pengujian untuk memeriksa konfigurasi dialplan dilakukan

C. Pengujian IP PBX

Pengujian selanjutnya dilakukan untuk mengetahui apakah Asterisk sudah terpasang pada server virtual. Verifikasi DAHDI dan LibPRI juga dilakukan pada tahapan ini. Gambar 10 menunjukkan tampilan terminal Asterisk.

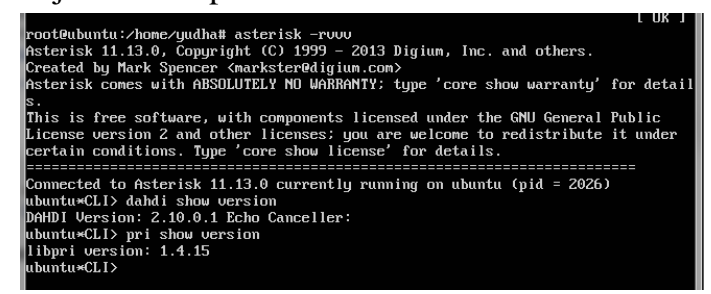
melalui terminal Asterisk dengan mengetikan perintah berikut: untu*CLI> dialplan show

Konfigurasi yang dibuat pada tahap konfigurasi sistem dikenali oleh IP PBX sebagai pbx_config. Gambar 11 menunjukkan tampilan pengecekan dialplan. 


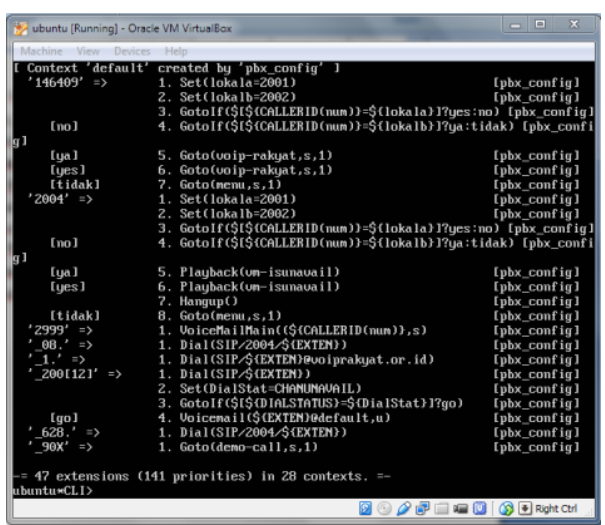

Gambar 11 Tampilan pengecekan dialplan

Kemudian pengujian untuk memeriksa konfigurasi klien SIP dilakukan melalui terminal Asterisk dengan mengetikan perintah berikut:

ubuntu*CLI> sip show peers

Perintah tersebut dilakukan untuk menampilkan informasi mengenai akun SIP yang telah terdaftar dalam IP PBX. Gambar 12 menunjukkan tampilan pengecekan status klien.

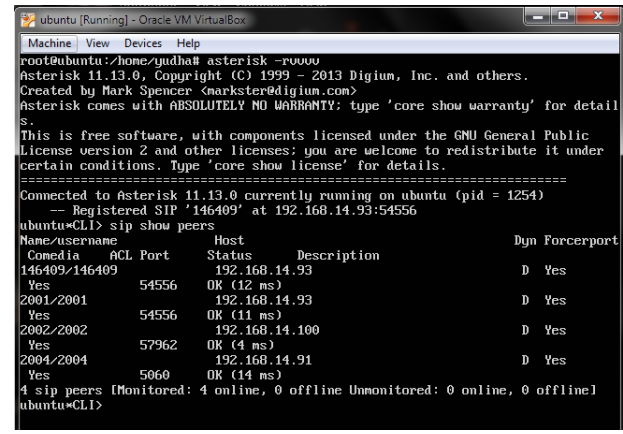

Gambar 12 Tampilan pengecekan status klien

Tahap terakhir pada pengujian IP PBX adalah pengujian yang dilakukan untuk memeriksa konfigurasi voicemail atau layanan kotak suara yang dilakukan melalui terminal Asterisk dengan mengetikan perintah berikut:

ubuntu*CLI> voicemail show users

Perintah tersebut dilakukan untuk menampilkan informasi mengenai akun SIP yang memiliki akun kotak suara dalam IP PBX. Gambar 13 menunjukkan tampilan pengecekan layanan kotak suara.

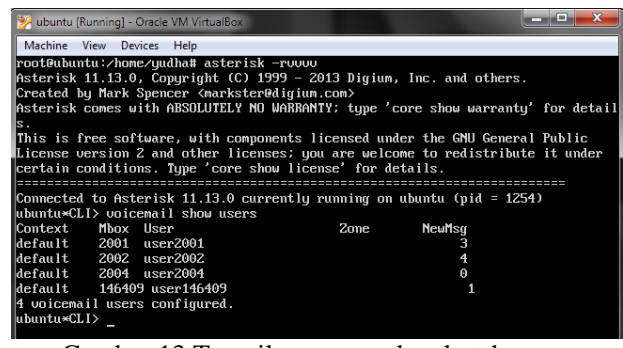

Gambar 13 Tampilan pengecekan kotak suara

D. Pengujian Ketersediaan Akun Klien

1) Pengujian ketersediaan akun Join

Akun Join dengan nomor ekstensi 2001 didaftarkan kepada softphone Join, dengan memasukkan informasi akun klien Join, yang telah didaftarkan pada tahap konfigurasi dalam IP PBX. Pendaftaran akun Join kepada softphone ditampilkan pada Gambar 14.

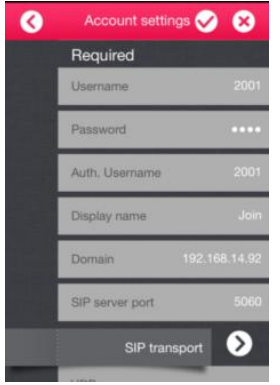

Gambar 14 Pendaftaran Akun Join kepada softphone

Saat proses pendaftaran selesai, akun Join dapat digunakan sebagai klien SIP yang dapat membuat dan menerima panggilan. Tampilan bahwa akun telah siap digunakan ditampilkan oleh Gambar 15.

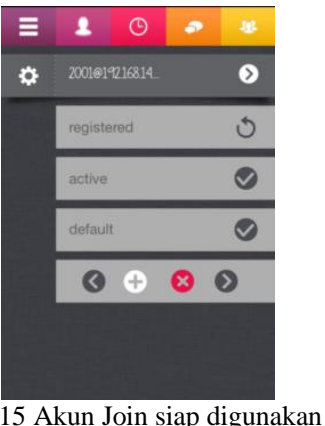

2) Pengujian ketersediaan akun Join

Akun X-Lite dengan nomor ekstensi 2002 didaftarkan kepada softphone X-Lite, dengan memasukkan informasi akun klien X-lite, yang telah didaftarkan pada tahap konfigurasi dalam IP PBX. Pendaftaran akun X-lite kepada softphone ditampilkan pada Gambar 16.

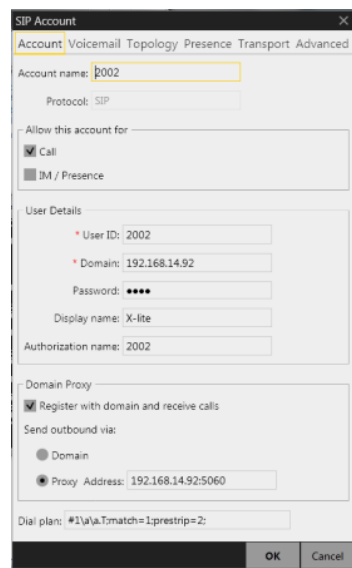

Gambar 16 Pendaftaran Akun X-lite kepada softphone

Saat proses pendaftaran selesai, akun X-lite dapat digunakan sebagai klien SIP yang dapat membuat dan menerima panggilan. Tampilan bahwa akun telah siap digunakan ditampilkan oleh Gambar 17.

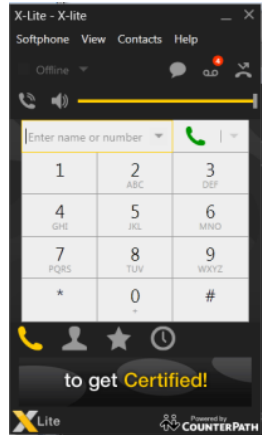

Gambar 17 Akun X-lite telah siap digunakan

3) Pengujian ketersediaan akun GSM

Tahap ini adalah tahap untuk mengetahui ketersedian klien GSM pada GSM Gateway. Akun GSM telah didaftarkan kepada GSM Gateway melalui web browser pada tahapan 
konfigurasi GSM gateway. Tampilan bahwa nomor ekstensi 082137508567 telah siap digunakan ditampilkan oleh Gambar 18.

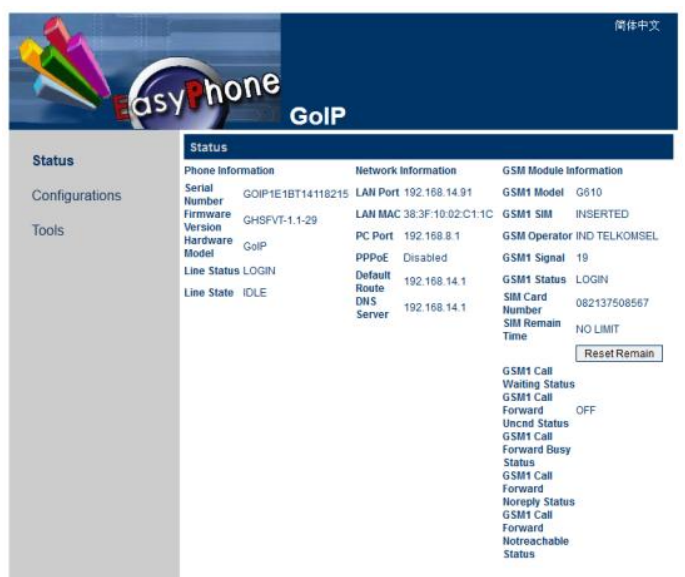

Gambar 18 Tampilan halaman web bahwa akun telah siap digunakan

4) Pengujian ketersediaan akun VoIP Rakyat

Server VoIP Rakyat akan merespon pendaftaran akun yang dilakukan IP PBX dengan memberikan notifikasi bahwa pendaftaran akun dan modul-modul yang dibutuhkan telah berhasil. Pendaftaran tersebut dikenali oleh server VoIP Rakyat sebagai pendaftaran klien SIP, yang dilakukan oleh server sistem telekomunikasi ini agar sistem dapat saling berkomunikasi. Keberhasilan pendaftaran ditampilkan oleh terminal Asterisk yang ditunjukkan pada Gambar 19.

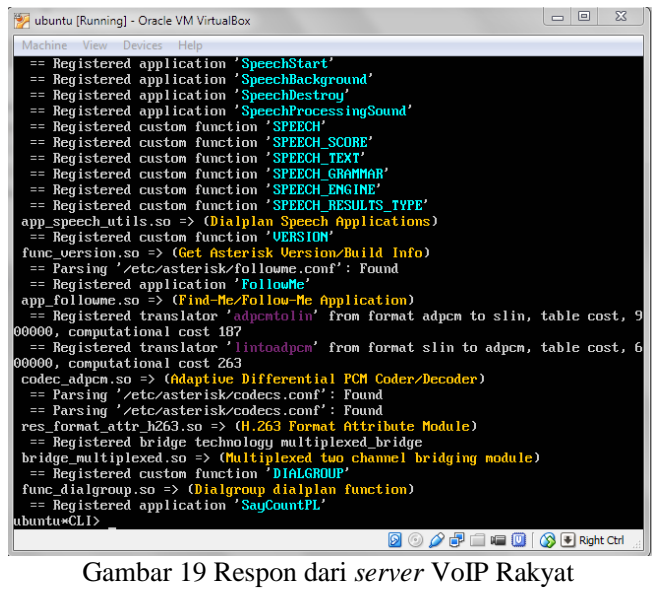

Dengan demikian, akun tersebut telah berhasil berfungsi sebagai perantara dalam menghubungkan kedua server ketika sebuah panggilan terjadi. Kemudian, akun VoIP Rakyat dengan nomor ekstensi 146409 didaftarkan kepada softphone Join. Dengan memasukkan informasi akun klien VoIP Rakyat yang telah didaftarkan pada tahap konfigurasi dalam IP PBX. Pendaftaran akun VoIP Rakyat kepada softphone ditampilkan pada Gambar 20.

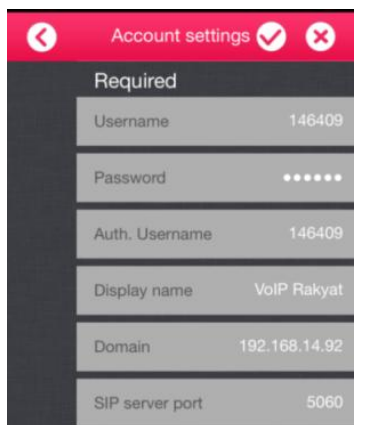

Gambar 20 Pendaftaran akun VoIP Rakyat kepada softphone

Saat proses pendaftaran selesai, akun VoIP Rakyat dapat digunakan sebagai klien SIP yang dapat membuat dan menerima panggilan. Tampilan bahwa akun telah siap digunakan ditampilkan oleh Gambar 21.

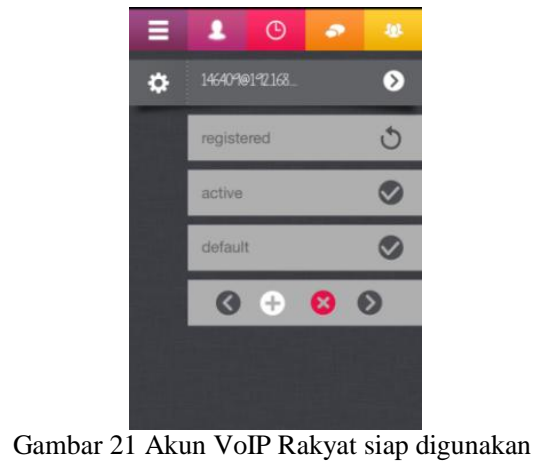

E. Pengujian Panggilan

1) Pengujian Panggilan Keluar

Pengujian dilakukan pada klien Join, X-lite dan VoIP Rakyat menggunakan softphone dengan nomor ekstensi tujuan yang terdapat dalam jaringan lokal, jaringan GSM dan jaringan VoIP Rakyat.

- Pengujian Panggilan Keluar dengan Klien Join

Pengujian panggilan pertama dilakukan dengan tujuan nomor ekstensi 2002 yaitu klien X-lite. Gambar 22 menunjukkan tampilan softphone Join ketika klien Join melakukan panggilan kepada klien X-lite dan Gambar 23 menunjukkan tampilan softphone Join ketika panggilan terhubung.

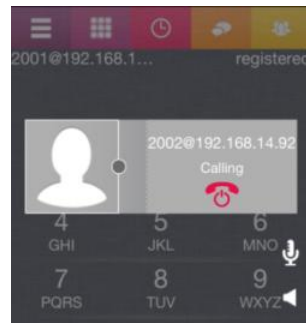

Gambar 22 Klien Join membuat panggilan kepada klien X-lite

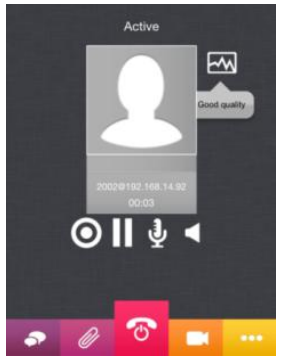

Gambar 23 Klien Join dan klien X-lite terhubung

Selama panggilan berlangsung, terminal Asterisk menampilkan informasi mengenai aktifitas yang terjadi selama panggilan. Gambar 24 menampilkan terminal Asterisk saat panggilan klien Join dan klien X-lite berlangsung.

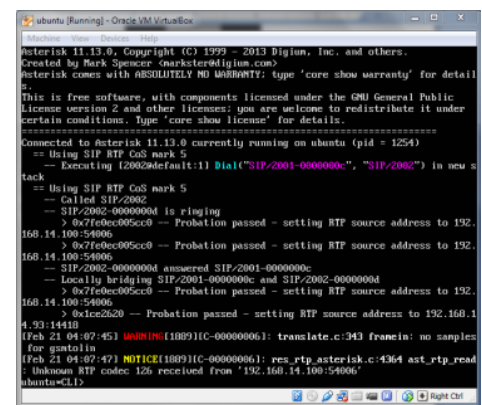

Gambar 24 Terminal Asterisk saat panggilan klien Join dan klien X-lite berlangsung

Gambar 24 menunjukkan bahwa IP PBX mengeksekusi panggilan yang dibuat oleh SIP/2001 dan ditujukan kepada SIP/2002. Dengan demikian hal tersebut menunjukkan bahwa panggilan ini telah sesuai dengan konfigurasi dialplan.

Klien Join melakukan panggilan terhadap klien VoIP Rakyat dengan nomor ekstensi 146409. Gambar 25 Jurnal Teknologi dan Sistem Komputer, Vol.3, No.2, April 2015 (e-ISSN: 2338-0403)
JTsiskom - 288 
menunjukkan tampilan softphone Join saat klien Join membuat panggilan kepada klien VoIP Rakyat dan Gambar 26 menunjukkan tampilan ketika panggilan terhubung.

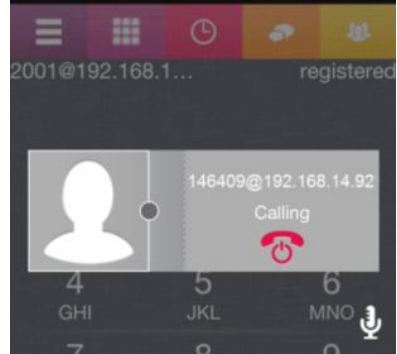

Gambar 25 Klien Join membuat panggilan kepada klien VoIP Rakyat

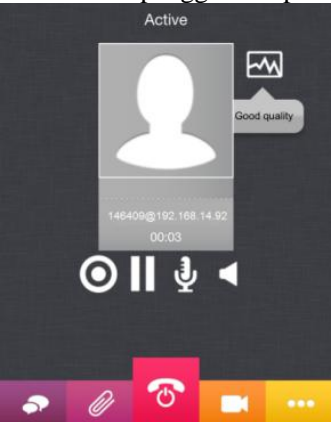

Gambar 26 Klien Join dan klien VoIP Rakyat terhubung

Gambar 27 menampilkan terminal Asterisk saat panggilan klien Join dan klien VoIP Rakyat berlangsung.

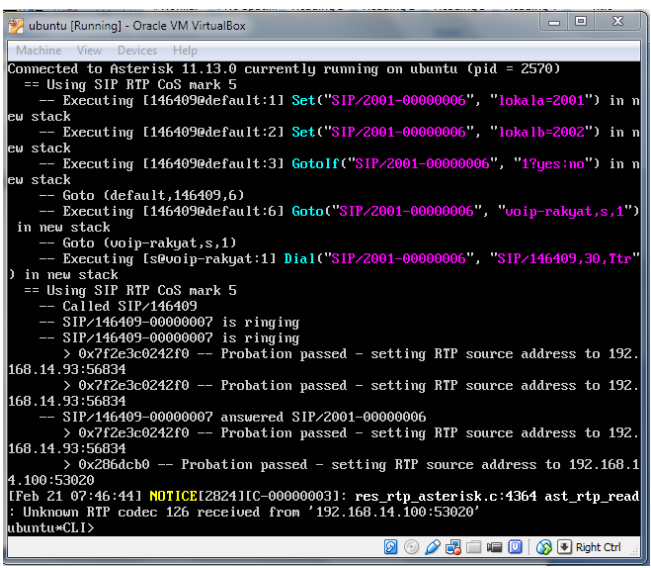

Gambar 27 Terminal Asterisk saat panggilan klien Join dan klien VoIP Rakyat berlangsung

Gambar 27 menunjukkan bahwa IP PBX mengeksekusi panggilan yang dibuat oleh SIP/2001 dan ditujukan kepada SIP/146409. Dengan demikian hal tersebut menunjukkan bahwa panggilan ini telah sesuai dengan konfigurasi dialplan.

Klien Join melakukan panggilan terhadap pengguna yang berada di dalam jaringan VoIP Rakyat dengan nomor ekstensi 150787. Gambar 28 menunjukkan tampilan softphone Join ketika klien Join membuat panggilan kepada pengguna VoIP Rakyat dan Gambar 29 menunjukkan tampilan ketika panggilan terhubung.

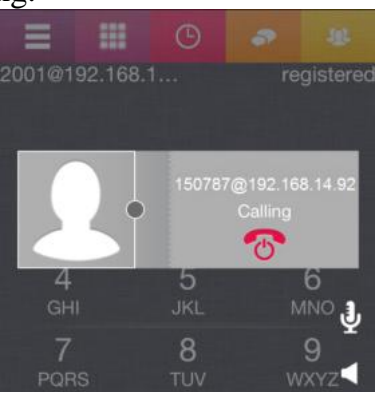

Gambar 28 Klien Join membuat panggilan kepada pengguna jaringan VoIP Rakyat

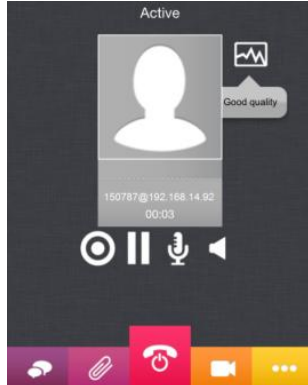

Gambar 29 Klien Join dan pengguna jaringan VoIP Rakyat terhubung Gambar 30 menampilkan terminal Asterisk saat panggilan klien Join dan pengguna jaringan VoIP Rakyat berlangsung.

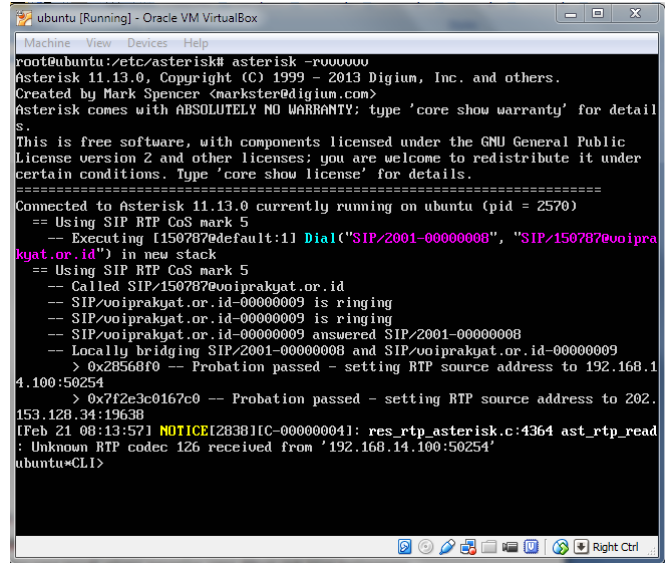

Gambar 30 Terminal Asterisk saat panggilan klien Join dan pengguna jaringan VoIP Rakyat berlangsung

Gambar 30 menunjukkan bahwa IP PBX mengeksekusi panggilan yang dibuat oleh SIP/2001, dan ditujukan kepada SIP/150787 melalui domain voiprakyat.or.id, menggunakan jaringan internet. Dengan demikian hal tersebut menunjukkan bahwa panggilan ini telah sesuai dengan konfigurasi dialplan.

Klien Join melakukan panggilan terhadap pengguna yang berada di dalam jaringan GSM dengan nomor ekstensi 085695623338. Gambar 31 menunjukkan tampilan softphone Join ketika klien Join membuat panggilan kepada pengguna jaringan GSM. Gambar 32 menunjukkan tampilan ketika panggilan terhubung.

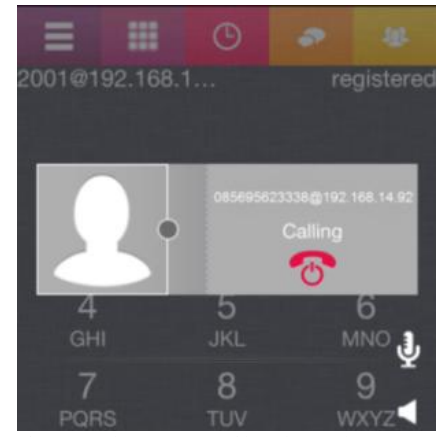

Gambar 31 Klien Join membuat panggilan kepada pengguna jaringan GSM

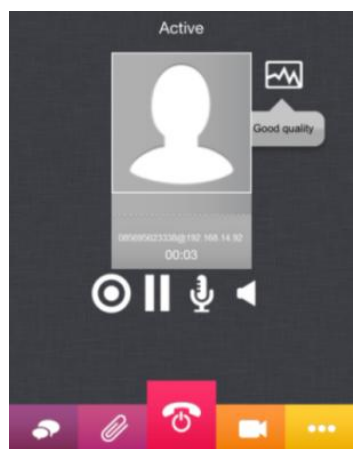

Gambar 32 Klien Join dan pengguna jaringan GSM terhubung

Saat panggilan kepada pengguna GSM dibuat, terdapat rentang waktu selama 8 detik sebelum klien ini bisa terhubung dengan jaringan GSM. Hal ini dikarenakan GSM gateway 
memerlukan waktu untuk mengkonversi panggilan SIP, menjadi panggilan di dalam jaringan GSM. Gambar 33 menampilkan terminal Asterisk saat panggilan klien Join dan pengguna jaringan GSM berlangsung.

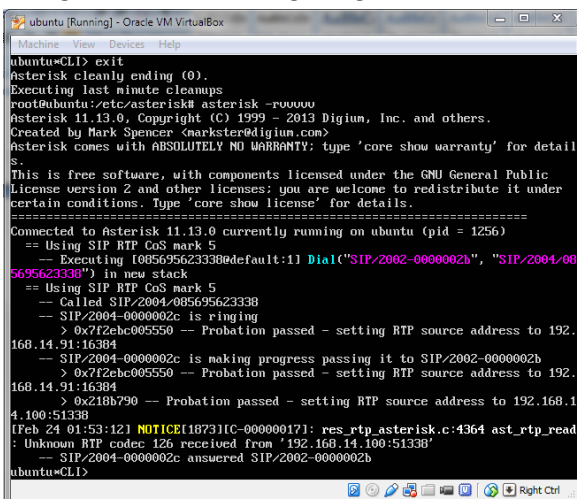

Gambar 33 Terminal Asterisk saat panggilan klien Join dan pengguna jaringan GSM berlangsung

- Pengujian Panggilan Keluar dengan Klien X-lite

Pengujian panggilan pertama dilakukan dengan tujuan nomor ekstensi 2001 yaitu klien Join. Gambar 34 menunjukkan tampilan softphone X-Lite ketika klien X-lite melakukan panggilan kepada klien Join, dan Gambar 35 menunjukkan tampilan softphone X-lite ketika panggilan terhubung.

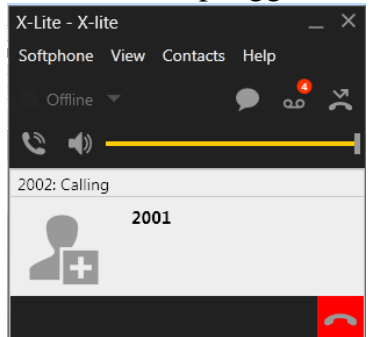

Gambar 34 Klien X-lite membuat panggilan kepada klien Join

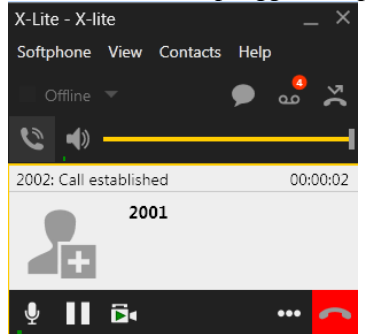

Gambar 35 Klien X-lite dan klien Join terhubung

Selama panggilan berlangsung, terminal Asterisk menampilkan informasi mengenai aktifitas yang terjadi selama panggilan. Gambar 36 menampilkan terminal Asterisk saat panggilan klien X-lite dan klien Join berlangsung.

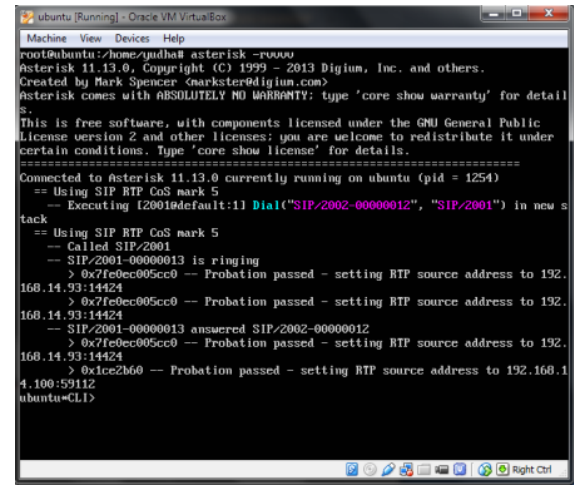

Gambar 36 Terminal Asterisk saat panggilan klien X-lite dan klien Join berlangsung

Gambar 36 menunjukkan bahwa IP PBX mengeksekusi panggilan yang dibuat oleh SIP/2002 dan ditujukan kepada $\mathrm{SIP} / 2001$. Dengan demikian hal tersebut menunjukkan bahwa panggilan ini telah sesuai dengan konfigurasi dialplan.

Klien X-lite melakukan panggilan terhadap klien VoIP Rakyat dengan nomor ekstensi 146409. Gambar 37

Jurnal Teknologi dan Sistem Komputer, Vol.3, No.2, April 2015 (e-ISSN: 2338-0403) menunjukkan tampilan softphone Join saat klien Join membuat panggilan kepada klien VoIP Rakyat dan Gambar 38 menunjukkan tampilan ketika panggilan terhubung.

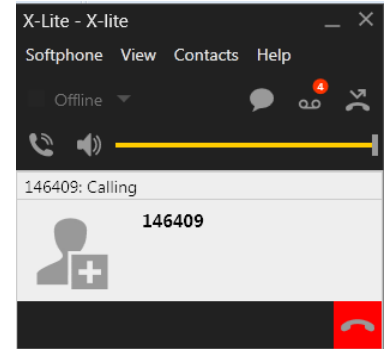

Gambar 37 Klien X-lite membuat panggilan kepada klien VoIP Rakyat

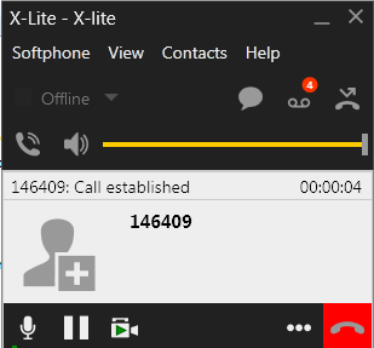

Gambar 38 Klien X-lite dan klien VoIP Rakyat terhubung

Gambar 39 menampilkan terminal Asterisk saat panggilan klien X-lite dan klien VoIP Rakyat berlangsung.

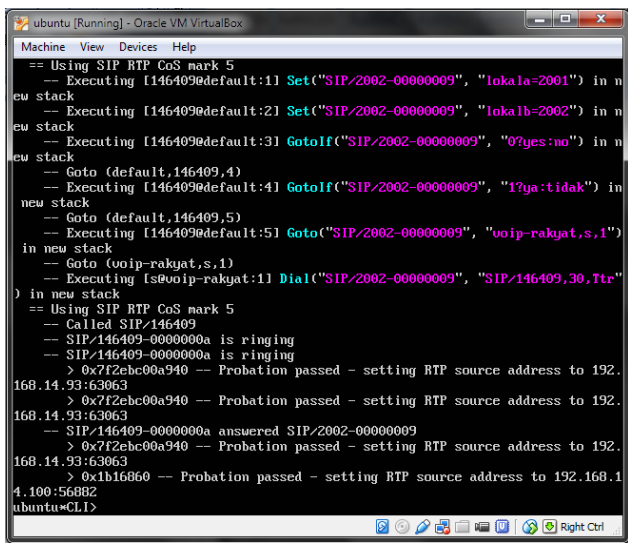

Gambar 39 Terminal Asterisk saat panggilan klien X-lite dan klien VoIP Rakyat berlangsung

Gambar 39 menunjukkan bahwa IP PBX mengeksekusi panggilan yang dibuat oleh SIP/2002 dan ditujukan kepada SIP/146409. Dengan demikian hal tersebut menunjukkan bahwa panggilan ini telah sesuai dengan konfigurasi dialplan.

Klien X-lite melakukan panggilan terhadap klien yang berada di dalam jaringan VoIP Rakyat dengan nomor ekstensi 150787. Gambar 40 menunjukkan tampilan softphone X-Lite ketika klien X-lite membuat panggilan kepada pengguna VoIP Rakyat dan Gambar 41 menunjukkan tampilan ketika panggilan terhubung.

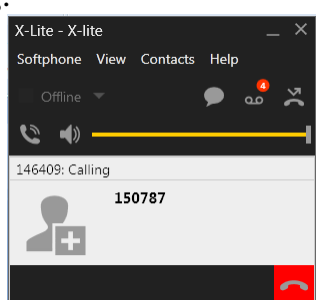

Gambar 40 Klien X-lite membuat panggilan kepada pengguna jaringan VoIP

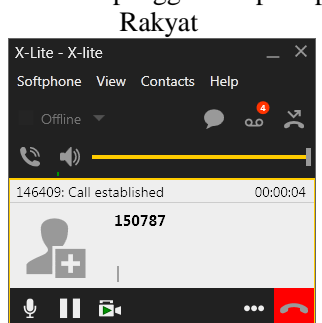

Gambar 41 Klien X-lite dan pengguna jaringan VoIP Rakyat terhubung 
Gambar 42 menampilkan terminal Asterisk saat panggilan klien X-lite dan klien Join berlangsung.

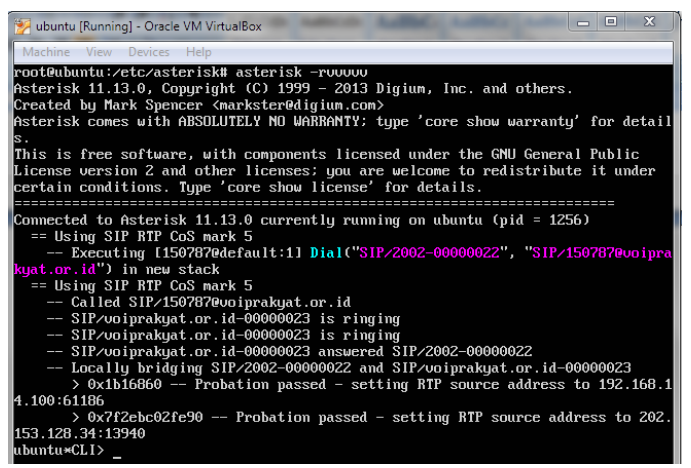

Gambar 42 Terminal Asterisk saat panggilan klien X-lite dan pengguna jaringan VoIP Rakyat berlangsung

Gambar 42 menunjukkan bahwa IP PBX mengeksekusi panggilan yang dibuat oleh SIP/2002 dan ditujukan kepada SIP/150787 melalui domain voiprakyat.or.id menggunakan jaringan internet. Dengan demikian hal tersebut menunjukkan bahwa panggilan ini telah sesuai dengan konfigurasi dialplan.

Klien X-lite melakukan panggilan terhadap klien yang berada di dalam jaringan GSM dengan nomor ekstensi 085695623338. Gambar 43 menunjukkan tampilan softphone X-Lite ketika klien X-lite membuat panggilan kepada pengguna VoIP Rakyat dan Gambar 44 menunjukkan tampilan ketika panggilan terhubung.

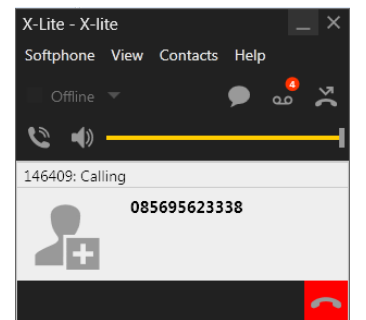

Gambar 43 Klien X-lite membuat panggilan kepada pengguna jaringan GSM

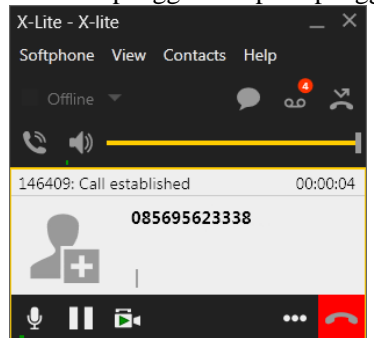

Gambar 44 Klien X-lite dan pengguna jaringan GSM terhubung

Saat panggilan kepada pengguna GSM dibuat, terdapat rentang waktu selama 8 detik sebelum klien ini bisa terhubung dengan jaringan GSM. Hal ini dikarenakan GSM gateway memerlukan waktu untuk melakukan call setup agar dapat terhubung dengan jaringan GSM. Gambar 45 menampilkan terminal Asterisk saat panggilan klien X-lite dan pengguna jaringan GSM berlangsung.

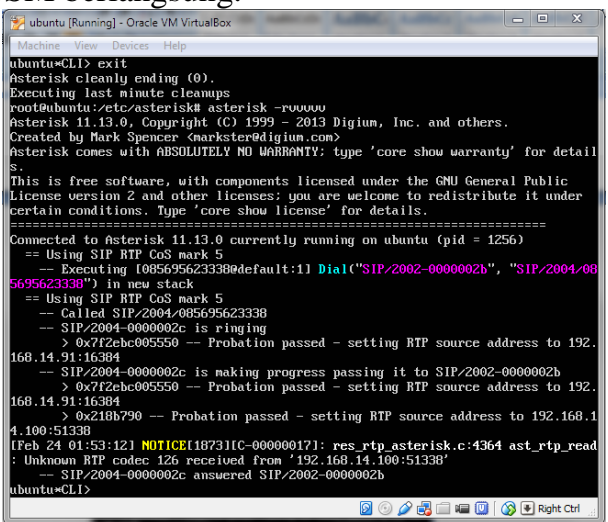

Gambar 45 Terminal Asterisk saat panggilan klien X-lite dan pengguna Jurnal Teknologi aan GSM berlangsung
- Pengujian Panggilan Keluar dengan Klien VoIP Rakyat

Klien VoIP Rakyat melalui tahap pengujian yang telah dilakukan pada klien Join, dikarenakan klien ini menggunakan softphone yang sama dengan klien Join, maka pengujian panggilan keluar pada Klien VoIP Rakyat tidak dicantumkan dalam pengujian ini. Perbedaan yang terdapat pada informasi terminal Asterisk hanya terdapat pada identitas pembuat panggilan, dalam tahap ini ditampilkan sebagai SIP/146409. Dengan demikian, setiap klien telah berhasil membuat panggilan yang sesuai dengan konfigurasi dialplan.

2) Pengujian Panggilan Masuk

Pengujian dilakukan pada klien Join, X-lite dan VoIP Rakyat menggunakan softphone dengan menerima panggilan yang masuk dari jaringan lokal, jaringan GSM dan jaringan VoIP Rakyat. Tampilan mengenai informasi yang diberikan pada terminal Asterisk tidak ditampilkan pada pengujian ini, hal tersebut dikarenakan terminal Asterisk menampilkan informasi yang sama dengan informasi yang terdapat pada pengujian panggilan keluar.

- Pengujian Panggilan Masuk dengan Klien Join

Penulis melakukan pengujian dengan menguji panggilan masuk yang berasal dari klien X-lite, klien VoIP Rakyat, pengguna jaringan VoIP Rakyat dan pengguna jaringan GSM. Gambar 46 menunjukkan tampilan ketika klien Join mendapat panggilan masuk dari klien X-lite, Gambar 47 menunjukkan tampilan ketika klien Join mendapat panggilan masuk dari klien VoIP Rakyat, Gambar 48 menunjukkan tampilan ketika klien Join mendapat panggilan masuk dari pengguna jaringan VoIP Rakyat dan Gambar 49 menunjukkan tampilan ketika klien Join mendapat panggilan masuk dari pengguna jaringan GSM.

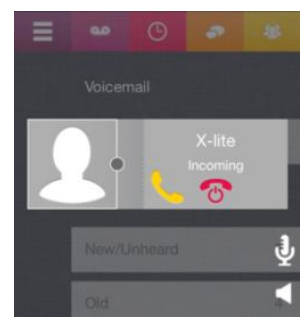

Gambar 46 Klien Join mendapat panggilan dari klien X-lite

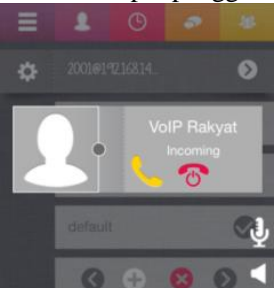

Gambar 47 Klien Join mendapat panggilan dari klien VoIP Rakyat

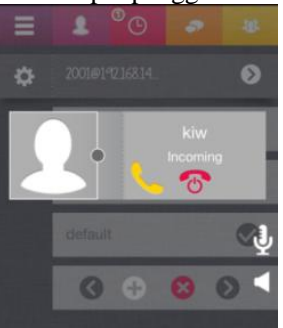

Gambar 48 Klien Join mendapat panggilan dari pengguna jaringan VoIP

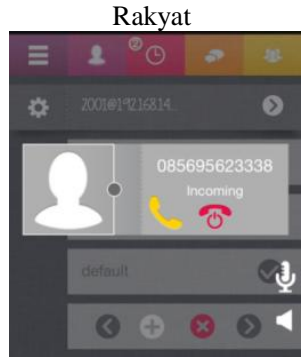
Gambar 49 Klien Join mendapat panggilan dari pengguna jaringan GSM
JTsiskom - 291 
Gambar 48 dan Gambar 49 menunjukkan bahwa klien Join dapat menerima panggilan dari jaringan VoIP Rakyat dan jaringan GSM, sebelum diarahkan kepada klien Join server IP PBX menerima panggilan tersebut yang direspon oleh teknologi IVR.

- Pengujian Panggilan Masuk dengan Klien X-lite

Kemudian pengujian dilakukan dengan menguji panggilan masuk yang berasal dari klien Join, klien VoIP Rakyat, pengguna jaringan VoIP Rakyat dan pengguna jaringan GSM. Gambar 50 menunjukkan tampilan ketika klien X-lite mendapat panggilan masuk dari klien X-lite, Gambar 51 menunjukkan tampilan ketika klien X-lite mendapat panggilan masuk dari klien VoIP Rakyat, Gambar 52 menunjukkan tampilan ketika klien X-lite mendapat panggilan masuk dari pengguna jaringan VoIP Rakyat dan Gambar 53 menunjukkan tampilan ketika klien X-lite mendapat panggilan masuk dari pengguna jaringan GSM.

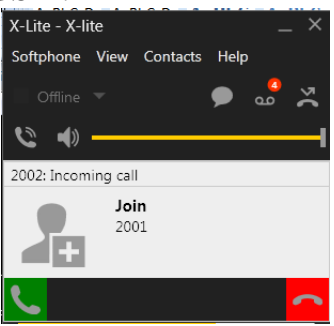

Gambar 50 Klien X-lite mendapat panggilan dari klien Join

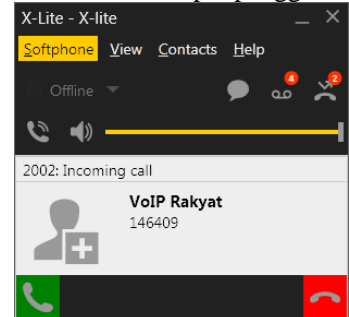

Gambar 51 Klien X-lite mendapat panggilan dari klien VoIP Rakyat

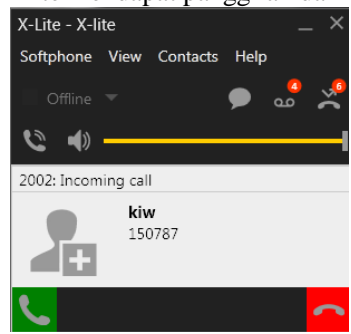

Gambar 52 Klien X-lite mendapat panggilan dari pengguna jaringan VoIP

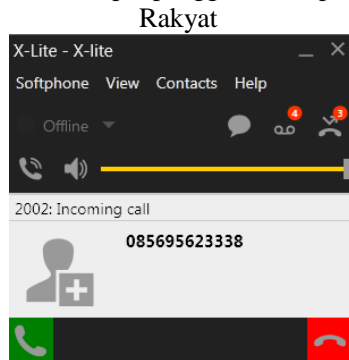

Gambar 53 Klien X-lite mendapat panggilan dari pengguna jaringan GSM

Gambar 52 dan Gambar 53 menunjukkan bahwa klien Xlite dapat menerima panggilan dari jaringan VoIP Rakyat dan jaringan GSM, sebelum diarahkan kepada klien Join server IP PBX menerima panggilan tersebut yang direspon oleh teknologi IVR.

- Pengujian Panggilan Masuk dengan Klien VoIP Rakyat

Seperti dalam pengujian panggilan keluar, pengujian panggilan masuk pada Klien VoIP Rakyat tidak dicantumkan dalam pengujian ini. Hal ini dikarenakan klien VoIP Rakyat menggunakan softphone yang sama dengan klien Join, sehingga tidak terdapat perbedaan tampilan ketika panggilan masuk terjadi.

\section{F. Pengujian Interactive Voice Response (IVR)}

Pengujian dilakukan dengan melihat terminal Asterisk untuk mengetahui apakah konfigurasi IVR yang dilakukan pada tahap sebelumnya telah berhasil diterapkan. Ketika panggilan yang masuk dijawab oleh IVR maka IVR akan merespon dengan memberikan informasi mengenai klien yang tersedia, yaitu A sebagai klien Join, B sebagai klien X-lite dan C sebagai klien VoIP Rakyat. Tampilan terminal Asterisk ketika IVR merespon panggilan masuk ditunjukkan oleh Gambar 54 .

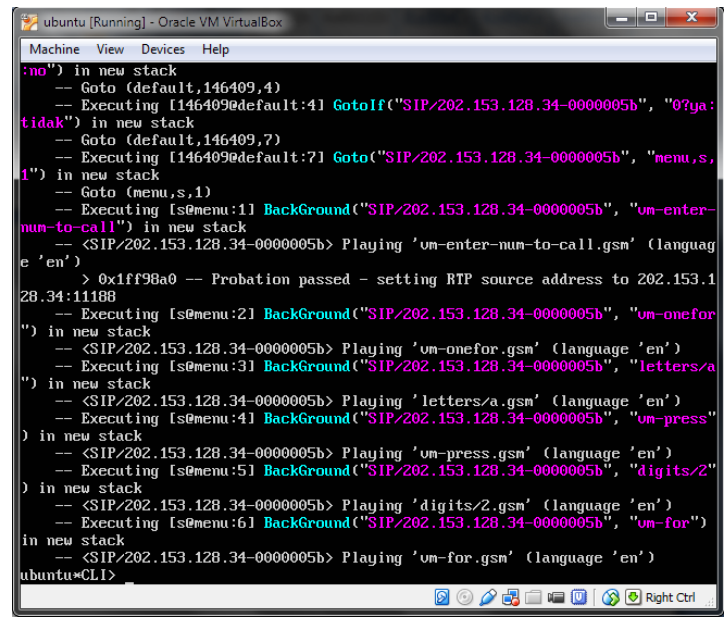

Gambar 54 Tampilan terminal Asterisk ketika IVR merespon panggilan

IVR akan menunggu masukan DTMF dari pemanggil yang kemudian masukan tersebut akan diarahkan kepada panggilan tujuan, disesuaikan dengan masukan tersebut. Gambar 55 menunjukkan respon IVR ketika menerima masukan dari pemanggil.

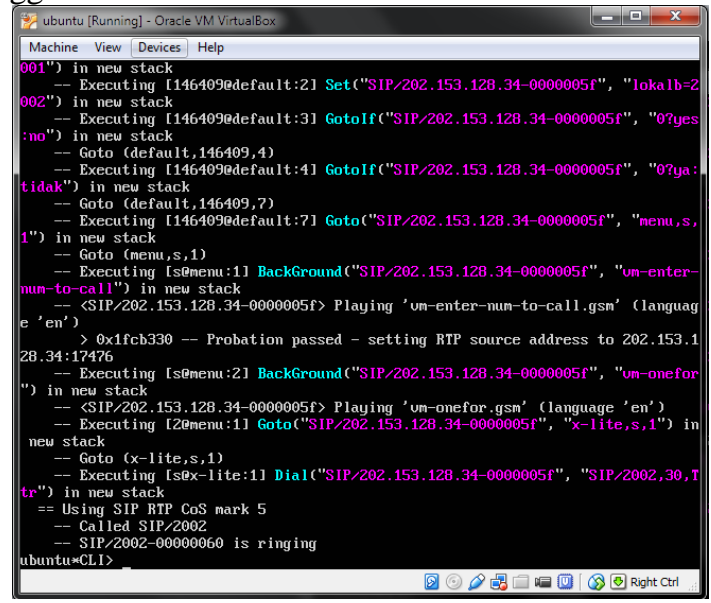

Gambar 55 Respon IVR ketika menerima masukan dari pemanggil

Gambar 55 menunjukkan bahwa pemanggil memberikan masukan berupa angka 2 sehingga IVR merespon masukan tersebut dengan membuat panggilan terhadap klien $\mathrm{X}$-lite. Apabila pemanggil menekan tombol 1 atau 3 maka IVR akan membaut panggilan kepada klien Join atau VoIP Rakyat. Dalam pengujian ini, pemanggil didefinisikan sebagai pengguna di luar sistem yang membuat panggilan. Pengguna tersebut berasal dari jaringan GSM atau jaringan VoIP Rakyat.

\section{G. Pengujian Kotak Suara (Voicemail)}

Pengujian kotak suara dalam penulisan tugas akhir ini dilakukan dengan melihat pada terminal Asterisk apakah server IP PBX mengarahkan panggilan kepada layanan kotak suara ketika klien di dalam sistem berstatus tidak aktif atau menolak panggilan yang masuk. Gambar 56 menunjukkan terminal asterisk saat pengujian layanan kotak suara (voicemail). 


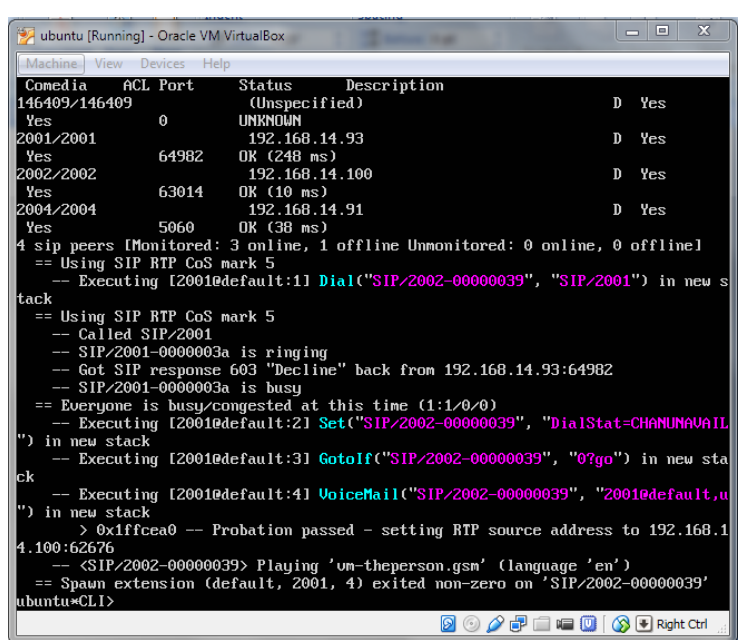

Gambar 56 Terminal Asterisk saat pengujian layanan kotak suara

Gambar 56 menunjukkan bahwa, sistem akan menginformasikan kepada pemanggil untuk meninggalkan pesan karena klien menolak, atau tidak dapat menerima panggilan. Apabila klien berstatus tidak aktif mendapatkan panggilan, maka panggilan yang masuk akan diarahkan kepada layanan kotak suara. Tampilan terminal asterisk mengenai panggilan kepada klien yang tidak aktif ditunjukkan oleh Gambar 57.

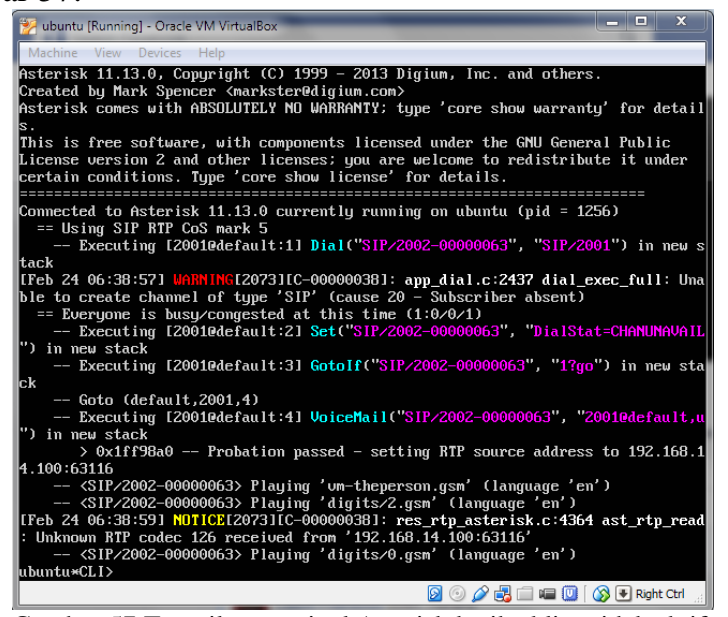

Gambar 57 Tampilan terminal Asterisk ketika klien tidak aktif

Klien di dalam sistem ini dapat mendengarkan pesan yang ditinggalkan oleh pemanggil dengan menghubungi nomor ekstensi 2999. Setiap pesan yang ditinggalkan untuk klien disimpan dalam direktori yang terdapat pada server yaitu /var/spool/asterisk/voicemail/default/user/. Tampilan terminal Asterisk mengenai pembacaan pesan yang ditinggalkan pemanggil pada kotak suara ditunjukkan oleh Gambar 4.71.

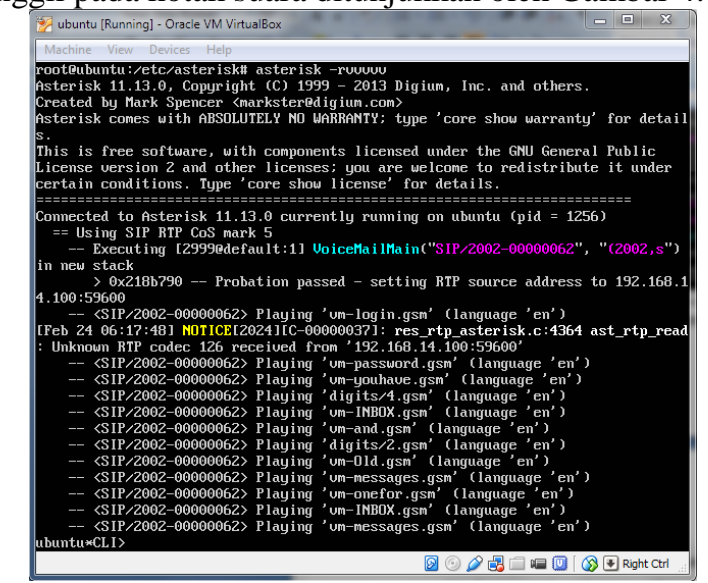

Gambar 58 Tampilan terminal Asterisk ketika menghubungi 2999

\section{H. Rekam Jejak Panggilan dengan Call Detail Record (CDR)}

Seluruh aktifitas panggilan yang telah terjadi dicatat oleh Asterisk dalam sebuah berkas dokumentasi yang terletak pada direktori /var/log/asterisk/cdr-csv/ dengan berkas bernama Master.csv. Untuk mengakses berkas tersebut, penulis menggunakan aplikasi WinSCP agar berkas tersebut dapat dibaca melalui aplikasi pengolah data. Berkas disimpan di dalam direktori Sistem Operasi Windows 7. Gambar 59 menunjukkan pengambilan berkas menggunakan aplikasi WinSCP.

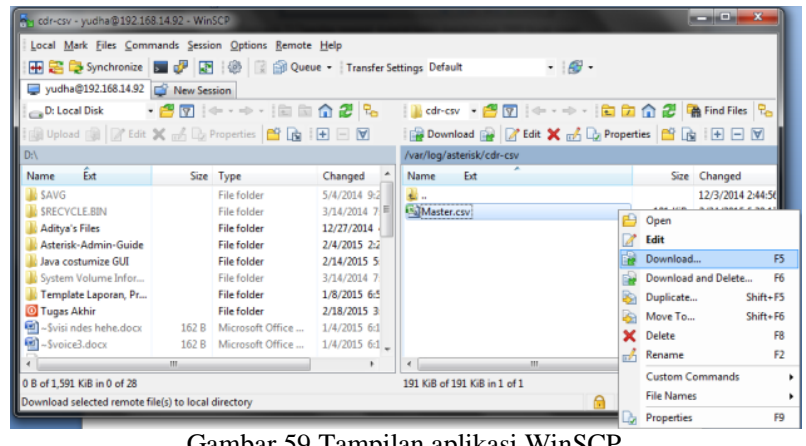

Gambar 59 Tampilan aplikasi WinSCP

Berkas tersebut dapat dibuka menggunakan aplikasi pengolah data. Gambar 4.73 menunjukkan tampilan mengenai isi berkas dokumentasi yang dicatat oleh Asterisk menggunakan fitur CDR.

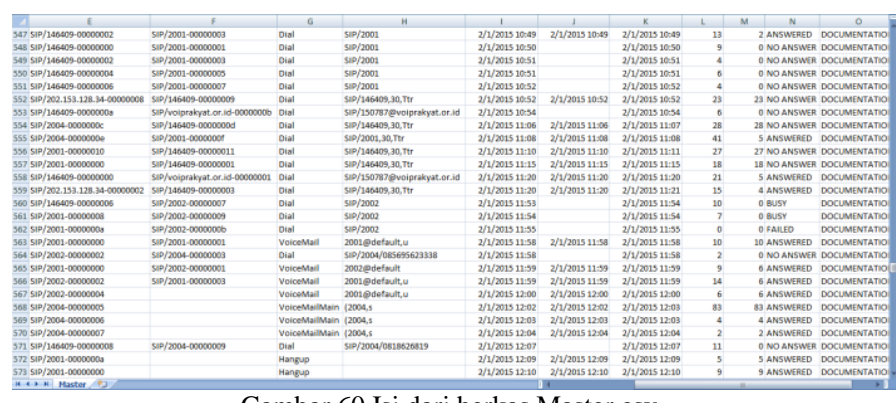

Berkas yang dihasilkan oleh fitur CDR berisi tentang klien pembuat panggilan, klien tujuan, alur panggilan, waktu panggilan, lamanya panggilan, status panggilan, dan jenis pencatatan.

\section{PENUTUP}

\section{A. Kesimpulan}

Selama perancangan dan pembangunan sistem telekomunikasi ini terdapat beberapa hal yang bisa disimpulkan. Kesimpulan yang didapatkan antara lain:

1. Rancang bangun sistem telekomunikasi berbasis VoIP telah berhasil dibangun dengan server virtual yang menjalankan IP PBX sebagai pusat kontrol dari sistem telekomunikasi ini.

2. Sistem telekomunikasi dapat berkomunikasi dengan jaringan lain yaitu Jaringan VoIP Rakyat (Internet) dan Jaringan GSM.

3. Sistem telekomunikasi dapat digunakan oleh pengguna yang terhubung dengan jaringan lokal melalui router nirkabel.

4. Sistem telekomunikasi memperkenankan pengguna jaringan GSM untuk berkomunikasi dengan klien berbasis VoIP.

5. Sistem telekomunikasi dapat memenuhi kebutuhan telekomunikasi seseorang dengan mobilitas tinggi yang disertai fleksibilitas dalam pengaturan alur panggilan.

6. Sistem telekomunikasi dapat mencatat dokumentasi panggilan guna memonitor aktifitas panggilan.

7. Implementasi sistem telekomunikasi tidak membutuhkan spesifikasi perangkat keras yang tinggi dikarenakan IP PBX diterapkan pada server virtual dengan spesifikasi yang minim. 
B. Saran

Adapun saran yang dapat diberikan sehubungan dengan pelaksanaan penelitian ini adalah:

1. Penelitian lanjutan untuk penambahan kanal pada GSM gateway agar sistem telekomunikasi dapat menggunakan kanal lain apabila terjadi dua buah panggilan atau lebih dengan jaringan GSM dalam waktu yang sama.

2. Sistem telekomunikasi ini dapat dikembangkan dengan menghubungkan sistem kepada jaringan PSTN agar konvergensi sistem lebih luas.

3. Penelitian lanjutan mengenai penambahan atribut pada CDR mengenai tarif dan fleksibilitas pengaturan pangilan dengan metode Least Cost Routing guna melakukan perbandingan tarif panggilan.

4. Penelitian lanjutan mengenai performansi sistem telekomunikasi konvergen berbasis VoIP menggunakan mesin virtual.

\section{DAFTAR PUSTAKA}

[1] E. D. Widianto and B. Maruddani, "Voip-Mobile Gateway Berbasis Opensource Asterisk," e-Indonesia Initiat., pp. 1-3, 2007.

[2] I. P. A. E. Pratama, Handbook Jaringan Komputer. Bandung: Informatika Bandung, 2014.

[3] B. Hartpence, Packet Guide to Voice Over IP. Sebastopol, California: O’Reilly Media, Inc., 2013.

[4] A. Vemuri-Pattisam and J. Peterson, "Session Initiation Protocol for Telephones : (SIP-T) Context and Architectures," RFC3372, 2002. [Online]. Available: http://www.rfc-editor.org/rfc/rfc3372.txt. [Accessed: 15-Jan-2015].
[5] A. F. Rochim, R. R. Isnanto, and D. B. Setiawan, "Voice Over Internet Protocol (VoIP) Menggunakan Asterisk Sebagai Session Initiation Protocol (SIP) Server," 2009.

[6] J. Eberspächer, H. Vögel, C. Bettstetter, and C. Hartmann, GSMArchitecture, Protocols and Services, Third. Chichester, UK: John Wiley \& Sons, Ltd., 2008.

[7] N. Deshpande, "Matlab implementation of GSM traffic channel," 2003.

[8] D. Lover, "VoIP Codecs." [Online]. Available: http://www.arrowsi.com/solutions/unified-communications/VOIPCODECS.html. [Accessed: 14-Jan-2015].

[9] H. Schulzrinne and S. Petrack, "RTP Payload for DTMF Digits, Telephony Tones and Telephony Signals," RFC2833, 2000. [Online]. Available: http://www.rfc-editor.org/rfc/rfc2833.txt. [Accessed: 15-Jan-2015].

[10] O. Hersent, J.-P. Petit, and D. Gurle, IP Telephony. Chichester, UK: John Wiley \& Sons, Ltd, 2005.

[11] O. W. Purbo and A. Raharja, VoIP Cookbook: Building your own Telecommunication Infrastructure. Jakarta: One Destination Center, 2010.

[12] K. Wallace, Implementing Cisco Unified Communications Voice over IP and QoS (CVOICE) Foundation Learing Guide. Indianapolis, 2011.

[13] R. Bryant, L. Madsen, and J. Van Meggelen, Asterisk ${ }^{T M}$ : The Definitive Guide. Sebastopol: O'Reilly Media, Inc., 2013.

[14] M. Spencer, "Introduction to the Asterisk Open Source PBX," pp. 116, 2002.

[15] A. A. Pangera and D. Ariyus, Sistem Operasi. Yogyakarta: ANDI, 2010. 